\title{
An Investigation of Antibiotic Resistance and Extended Spectrum Beta-Lactamase Presence in Escherichia coli Strains Isolated from Drinking Water Collected from Gümüşhane Province
}

öz

Su kaynaklı enfeksiyonlar dünya çapında önemli bir morbidite ve mortalite nedenidir. Arıtma tesisi çıkışında bakteriyel standartları sağlayan içme suyu, dağıtımı sırasında kirlenebilmekte ve bakteri sayısında artış meydana gelebilmektedir. Antimikrobiyal ajanların insanlardaki kullanım alanları dışında, hayvan yetiştiriciliği ile tarımda da kullanılması, antimikrobiyal dirençli mikroorganizmaların ortaya çıkmasına ve bunların doğaya özellikle su ve toprağa bulașmasına katkıda bulunmaktadır.

Bu çalısmada Gümüshane ili Halk Sağlığı Laboratuvarı'na kontrol izleme analizleri için getirilen içme sularından izole edilen Escherichia coli izolatlarında toplumda yaygın olarak kullanılan antibiyotiklere karşı direnç paterninin araştırılması amaçlanmıştır.

CCalışmaya 2016 yılı Haziran-Eylül ayları arasında, Gümüshhane ili ve çevresinden numune alma koşullarına uygun olarak alınan ve laboratuvara getirilen su örneklerinden izole edilen 50 adet E.coli izolatı dahil edilmistir. Örnekler membran filtrasyon yöntemi ile süzüldükten sonra Chromogenic Coliform Agar (CCA-sartorius, Almanya) besiyerine ekim yapılmış ve $36 \pm 2{ }^{\circ} \mathrm{C}$ 'de $21 \pm 3$ saat inkübasyona bırakılmıştır. Buradan izole edilen E.coli suşları standartta belirtildiği şekilde doğrulamaya alındıktan sonra suşların disk difüzyon yöntemi ile klinik tedavide sıklıkla kullanılan 13 adet antibiyotiğe karşı direnci test edilmiş ve genişlemiş spektrumlu betalaktamaz (GSBL) varlığı araştırılmıştır.

Çalışma sonunda E.coli izolatlarının 38'i test edilen tüm antibiyotiklere karşı duyarlı bulunurken, 12'si çeşitli antibiyotiklere direncli ya da orta duyarlı bulunmustur. izolatlar sefoksitine \% 16 direncli, \% 6 orta duyarlı: sefepime $\% 2$ direncli; seftazidime $\% 2$ direncli; ampisilin sulbaktama $\% 2$ direncli, \% 2 orta duyarli; piperasiline $\% 2$ dirençli; sefuroksime \% 2 dirençli, \% 6 orta duyarlı bulunmuştur. Trimetoprim/sülfametoksazol, ertapenem, ampisilin, gentamisin ve amikasine karşı herhangi bir dirence ve GSBL varlığına rastlanılmamıştır.

Bu çalışma, içme suyunda fekal kirlilik indikatörü olan E.coli izolatlarının bulunması içme suyunda fekal bir bulașın olduğunu gösterirken, üreyen E.coli izolatlarında antibiyotiklere direnç yönünden bu bölgede halk sağıı̆ıını tehdit edecek boyutta olmadığını düşündürmüştür.

Anahtar kelimeler: antibiyotik direnci, Escherichia coli, içme suyu

ABSTRACT

Waterborne infections are important causes of morbidity and mortality worldwide. Drinking water that adheres to the bacterial standards at the water treatment plant output may be contaminated during distribution and an increase in bacterial count may occur. The use of antimicrobial agents in animal husbandry and agriculture in addition to the uses in humans, contributes to the emergence of antimicrobial resistant microorganisms and their transmission to nature, especially to water and soil. The aim of this study was to determine the resistance of E.coli isolates isolated from drinking water and brought to the Public Health Laboratory of Gümüşhane province for control and follow-up analysis.

The study included 50 E.coli isolates isolated from the water samples collected from the samples taken from the province of Gümüshane and its surroudings from June to September 2016. The samples were drained by membrane filtration method and cultured on Chromogenic Coliform Agar (CCA-sartorius, Almanya) and incubated at $36 \pm 2{ }^{\circ} \mathrm{C}$ for $21 \pm 3$ hours. The isolated E.coli strains were confirmed as described in the standard and the resistance of the strains to 13 antibiotics, which were frequently used in clinical treatment, were tested by disc diffusion method and the presence of extended spectrum beta-lactamase (ESBL) was investigated.

At the end of the study, 38 of the E.coli isolates were susceptible to all tested antibiotics, while 12 of them were resistant or intermediate to various antibiotics. The isolates were $16 \%$ resistant, $6 \%$ intermediate to cefoxitine; $2 \%$ resistant to cefepime; $2 \%$ resistant to ceftazidime; $2 \%$ resistant, $2 \%$ intermediate to ampicillin sulbactam; $2 \%$ resistant to piperacillin; $2 \%$ resistant, $6 \%$ intermediate to cefuroxime. There was no resistance to trimethoprim/sulfamethoxazole, ertapenem, ampicillin, gentamicin and amikacin, and no ESBL presence.

This study showed fecal contamination in drinking water, because E.coli isolates, which are the indicator of fecal contamination were detected in drinking water. However, in terms of antimicrobial resistance in E.coli isolates, it suggested that the problem was not at threatening levels for the public.

Keywords: antibiotic resistance, drinking water, Escherichia coli
Alındığı tarih: 06.02.2019

Kabul tarihi: 22.04.2019

Yayın tarihi: 30.04 .2019

Figen Kayserili Orhan Atatürk Üniversitesi Sağlık Hizmetleri

Meslek Yüksekokulu

Erzurum - Türkiye

- figen.kayserili@hotmail.com ORCiD: 0000-0002-1839-3434

Ü. Altoparlak 0000-0003-4154-2116 Atatürk Üniversitesi Tıp Fakültesi Tıbbi Mikrobiyoloji Anabilim Dalı Erzurum - Türkiye

L. Odacı 0000-0002-9802-9439 Gümüşhane Halk Sağlığı Laboratuvarı Gümüşhane - Türkiye 
F. Kayserili Orhan ve ark., Gümüşhane İli İçme Sularından İzole Edilen Escherichia coli İzolatlarında Antibiyotik Direnci ve Genişlemiş Spektrumlu Beta-Laktamaz Varlığının Araştırılması

\section{Giriş̧}

Ülkemiz doğal su kaynakları yönünden oldukça zengindir. Ancak hızlı şehirleşme içilebilir suyun kalitesini dünya genelinde hızla azaltmakta ve bunu engellemek için pek fazla önlem alınmamaktadır. Sağlıklı ve güvenilir bir içme suyunun temin edilerek tüketiciye ulaştırılması toplum sağlığı için son derece önemlidir ${ }^{(11)}$.

İçme sularının mikroorganizma yükü ve bu mikroorganizmaların antibiyotik direnci halk sağlığı açısından önem arz etmektedir ${ }^{(2)}$. Antibiyotik dirençli bakteriler (ARB) ve antibiyotik direnç genleri (ARG), hem klinik hem de doğal ortamlarda, dünya çapında artık endişe verici boyuttadır ${ }^{(19)}$.

İçme suyu, Escherichia coli bakterisinin doğal yaşam ortamı değildir ve bu bakteriler temiz suda çoğalmazlar. E.coli'nin içme suyunda tespit edilmesi, bir ya da daha fazla aşamada doğrudan ya da dolaylı olarak suda fekal bulaşın göstergesidir ${ }^{(11)}$.

Insan bağırsak florasında R-plazmidleri taşıyan bakteriler yaygın olarak bulunur ve enterik bakterilerin rezervuarı olan kanalizasyon sularının arıtılmaksızın sucul ortamlara katılması, bu tip dirençli bakterilerin ve R-plazmidlerinin çevreye yayılmasına sebep olur ${ }^{(9)}$. Bir araştırmada, denizlerdeki bakteri popülasyonları arasında konjugasyon yoluyla yüksek düzeyde plazmid transferinin gerçekleştiği saptanmıştır(5).

Bu çalışmada Gümüşhane içme sularından izole edilen toplam 50 E.coli izolatının toplumda yaygın olarak kullanılan antibiyotiklere karşı direnç profilinin belirlenmesi amaçlanmıştır.

\section{GEREÇ VE YÖNTEM}

\section{Membran Filtrasyon Yöntemi ile E.coli Tayini}

Araştırmada materyal olarak, içme sularında fekal kirlilik indikatörü olan E.coli kullanılmıştır. Kontrol izleme analizi için 250 ml'lik steril tiyosülfat içeren numune kaplarında laboratuvara getirilen su numuneleri bekletilmeden işleme alınmış ve analizler TS EN ISO 9308-1 standardına göre gerçekleştirilmiştir. $100 \mathrm{ml}$ su numunesi $0.45 \mu \mathrm{m}$ por çaplı memb- ran filtreden süzülmüş ve CCA agar besiyeri (SartoriusAlmanya) üzerine konularak $36 \pm 2^{\circ} \mathrm{C}$ de, aerop ortamda $21 \pm 3$ saat inkübasyona bırakılmıştır. Daha sonra bakteri üremesi görülen plaklara standartta belirtildiği şekilde doğrulama yapılmış ve her bir plaktaki bir koloniden alınan E.coli örneği Eozin Metilen Blue (EMB) agara ekim yapılmış ve üreyen bakteriler konvansiyonel yöntemlerle doğrulanmıştır ${ }^{(16)}$.

\section{İzolatların Antibiyotik Direncinin Belirlenmesi}

İzole edilen E.coli suşlarının antibiyotik duyarlılık testleri Clinical and Laboratory Standards Institute (CLSI) kriterleri doğrultusunda Kirby-Bauer disk difüzyon yöntemine göre yapılmıştır. $0.5 \mathrm{McFarland}\left(10^{5}\right.$ cfu/ml) bulanıklığına ayarlanmış bakteri süspansiyonları Mueller Hinton agara ekilerek 24 saat sonunda izolatların toplam 13 adet antibiyotiğe karşı direnci test edilmiş, genişlemiş spektrumlu beta laktamaz (GSBL) varlığı ise çift disk sinerji yöntemi ile araştırılmış ve sonuçlar EUCAST kılavuzlarına göre değerlendirilmiştir ${ }^{(4,15)}$. Testin kalite kontrolü için $E$. coli ATCC 25922 referans suşu kullanılmıştır.

\section{BULGULAR}

İzole edilen E.coli izolatlarının 38'i test edilen tüm antibiyotiklere duyarlı bulunurken, 12'si çeşitli antibiyotiklere dirençli ya da artmış dozda duyarlı bulunmuştur. Çalışılan izolatların hiçbirinde GSBL varlığına rastlanılmamıştır. Antibiyogram testi sonuçları Tablo'da verilmiştir.

Tablo. Test edilen izolatların antibiyotik direnç oranları (\%).

\begin{tabular}{lccc}
\hline Antibiyotik & Duyarlı & $\begin{array}{c}\text { Artmış } \\
\text { dozda duyarlı }\end{array}$ & Dirençli \\
\hline Amikasin & 100 & 0 & 0 \\
Ampisilin sulbaktam & 96 & 2 & 2 \\
Ertapenem & 100 & 0 & 0 \\
Gentamisin & 100 & 0 & 0 \\
Imipenem & 100 & 0 & 0 \\
Piperasilin tazobaktam & 100 & 0 & 0 \\
Piperasilin & 98 & 0 & 2 \\
Siprofloksasin & 100 & 0 & 0 \\
Sefepim & 98 & 0 & 2 \\
Sefoksitin & 78 & 6 & 16 \\
Sefuroksim & 92 & 6 & 2 \\
Seftazidim & 98 & 0 & 2 \\
Trimetoprim sülfametoksazol & 100 & 0 & 0 \\
\hline
\end{tabular}




\section{TARTIŞMA}

Dünya üzerinde bozulmamış araziler hariç, yüzey sularında antibiyotiklerin tespit edilemediği bir alan bulmak artık zordur. Nehirler, kanalizasyonlar, okyanus suyu ve içme suyu da dahil olmak üzere çeşitli sucul ortamlarda antibiyotik direnci tespit edilmiştir(18,12).

Günümüzde akuatik ortamlarda $A R B$ ve ARG'lerin ortaya çıkışı ile ilgili artan bir endişe vardır ve su ortamı antibiyotik direncinin kazanılması ve yayılması için ideal bir ortam sağlar. ARB'lerin ortaya çıkışı ve yayılması, 21. yüzyılda küresel halk sağlığı için üçüncü en büyük tehdit olarak kabul edilmektedir(10).

Antibiyotikler insan ve hayvanlarda sadece tedavi edici olarak kullanılmayıp, koruyucu ya da büyüme promotörü olarak da kullanılabilmektedir. Spiramisin, tilosin, karbadoks, virginiamisin, monensin gibi büyüme promotörleri, insanların tedavisinde kullanılmamasına rağmen, diğer antibiyotiklere karşı çapraz direnç geliştirdiği düşünülmektedir ${ }^{(8)}$.

Sulardan izole edilen mikroorganizmaların antibiyotik direnç oranları bize bulaşmanın kentsel ya da kırsal kaynaklı olduğu hakkında bilgi verebilmektedir. Örneğin izole edilen bakterilerde çoklu antibiyotik direncinin olması, bulaşın antibiyotik kullanımı yoğun olan bir bölgeden olduğunu ya da hastane kökenli kanalizasyon suyu ile kontaminasyonun göstergesi olabilir ${ }^{(11)}$.

Günümüzde çevresel örneklerde antibiyotik direncine odaklanan çalışmaların çoğu, atık su arıtma tesis çıkışlarına yakın tarımsal havza ve nehirler gibi antropojenik faaliyetlerden önemli ölçüde etkilenen ciddi kirlilik veya sulara sahip su ortamlarında yapılmaktadır. Ancak içme suyu kaynağı gibi özel bir su ortamında antibiyotik direncinin varlığı ve dağılımı, her zaman ihmal edilmektedir. Literatürlere göre, içme suyu kaynaklarındaki antibiyotik direncinin oranı ciddi bir endişe kaynağıdır. Yurdumuzda bu konuda çalışmalar yapılmış ve enterik bakteriler arasında R plazmidlerine bağlı direnç özelliği oranının yüksek olduğu belirtilmiştir ${ }^{(3,17)}$.

E.coli, insan ve diğer sıcakkanlı hayvanların bağırsak florasındaki yaygın bakterilerden birisidir ve antibiyotik baskısına her zaman maruz kalmaktadır. E.coli su ortamında diğer bakterilere göre daha uzun süre (4 ile 12 hafta) yaşaması sebebiyle, ARG'lerin yaygınlaştırılmasına da katkıda bulunurlar. 1890'larda, su arıtma güvenliğinin biyolojik göstergesi olarak seçilen E.coli canlı ve cansız yüzeylerde biyofilm oluşturma yeteneğine sahip olup, oluşturduğu biyofilm yapısıyla zorlu çevre koşullarına, antibiyotiklere ve dezenfektanlara dirençli hale gelir ve antibiyotik direnç genleri için bir rezervuar görevi görür(6).

E.coli'nin sucul ortamlarda iyi hayatta kalabilen bir fırsatçı patojen olması ve antibiyotik direnç yayılımı için vektör olarak görülen yatay gen transferinde oldukça usta olması sebebiyle çalışmamızda bu bakteri tercih edilmiştir.

Yapılan çalışmalarda sağlıklı kişilerin dışkı örneklerinin \% 80.5'inin antibiyotiklere dirençli bakteri içerdiği tespit edilmiştir ve izole edilen bakterilerin \% 98'inin E.coli olduğu bildirilmiştir. Büyük bir arıtma tesisinin atık suyunda $10^{3} \mathrm{CFU} / \mathrm{ml}$ dirençli koliform bakteri izole edilmiş ve bunların \% 17'sinde antibiyotiklere karşı altı kat direnç tespit edilmiştir ${ }^{(14)}$. Akkan ve ark. $^{(1)}$ hastane atık sularıyla kontamine edilen deniz suyundan izole ettikleri Gram negatif bakterilerde sefazoline $\% 85$, sefuroksime $\% 28$, sefotaksime $\% 8$ ve sefepime karşı \% 5 oranında direnç tespit etmişlerdir. Ayrıca, izolatların \% 91'inin çoklu antibiyotik direnç (ÇAD) indeksi referans değer olan 0.2 'nin üzerinde saptamışlardır. Hastane atık sularının deşarj edildiği deniz suyundan izole edilen Gram negatif bakterilerin önemli oranda antibiyotik direncine sahip olduğunu ve bunun halk sağlığı açısından potansiyel bir risk oluşturabileceği sonucuna varmışlardır.

Çalışmamızda test edilen 13 antibiyotiğin altısına karşı dirençli E.coli izolatları bulunmuştur. Çalışmamızda en fazla direnç sefalosporin grubunda görülmüştür (\% 16 sefoksitin, \% 2 sefepim, \% 2 seftazidim, \% 2 sefuroksim). Test edilen E.coli izolatlarının birinde 2. 3. ve 4. kuşak sefalosporinlere karşı (sefoksitin, seftazidim ve. sefepime) direnç saptanmıştır. Bir izolatta ise sefoksitin, sefuroksim, piperasilin ve ampisilin sulbaktama karşı direnç görülmüştür. Iki 
F. Kayserili Orhan ve ark., Gümüşhane İli İçme Sularından İzole Edilen Escherichia coli İzolatlarında Antibiyotik Direnci ve Genişlemiş Spektrumlu Beta-Laktamaz Varlığının Araştırılması

izolat sefoksitin ve sefuroksime (2. kuşak sefalosporin), bir izolat sefoksitine, bir izolat ise sefuroksime orta duyarlı bulunmuştur.

Üçüncü kuşak sefalosporinlerle yapılan bir araştırmada, doğal dirençlilik frekans yüzdesinin, yüksek düzeyde olduğu ve bunun nozokomiyal atıklarla sucul ortama katılan antibiyotiklerden kaynaklandığı belirtilmiştir(9). Çalışmamızda en fazla direnç 2 . kuşak sefalosporin grubundan sefoksitine (\% 16) karşı görülmüştür.

Florokinolonlar tıp ve veteriner hekimliğinde yaygın olarak kullanilan antibiyotikler arasındadır. Siprofloksasin ise en çok tüketilen florokinolon grubu antibiyotiktir. Tetrasiklinler, sülfonamidler ve betalaktamlar gibi antibiyotikler, sadece bakteriyel enfeksiyonlari tedavi etmek için değil aynı zamanda gıda için kullanılan hayvanların büyüme hızını arttırmada gıda katkı maddeleri olarak da kullanılmaktadır ${ }^{(19)}$. Çalışmamızda florokinolon grubundan siprofloksasin çalışılmış ve harhangi bir dirence rastlanılmamıştır.

Reinthaler ve ark. ${ }^{(14)}$ Güney Avusturya'daki üç ayrı kanalizasyon arıtma tesisinden çıkan çamurdan izole ettikleri 767 E.coli izolatını, 24 farklı antibiyotik için test etmişler ve en yüksek direnci bir hastanenin kanalizasyonunu arıtan tesisten izole edilen E.coli suşlarında bulmuşlardır. Test edilen antimikrobiyal ajanlar arasında, penisilin grubundaki en yüksek direnç oranlarını ampisilin (\% 18) ve piperasiline (\% 12) karşı bulmuşlardır. Sefalosporin grubunda sefalotin \% 35 ve sefuroksim-aksetil için \% 11; kinoIonlar grubunda nalidiksik asit için $\% 15$ ve trimetop$\mathrm{rim} /$ sülfametoksazol için \% 13 ve tetrasiklin için \% 57 oranında direnç belirlemişlerdir.

Efuntoye ve ark. ${ }^{(7)}$ Nijerya'da 50 adet su kuyusundan topladıkları 200 su örneğinde yaptıkları çalışmada 96 izolatta yedi farklı cins bakteri izole etmiş (Escherichia, Bacillus, Proteus, Klebsiella, Pseudomonas, Staphylococcus ve Alcaligenes) ve en yüksek oranda direncin E.coli izolatlarında olduğunu bildirmişlerdir (\% 36.5). İzole edilen E.coli'lerin tümü amoksisilin/klavulanik asite dirençli bulunmuş, streptomisin, tetrasiklin, ampisilin ve vankomisine direnç oranları ise sırasıyla \% 71.4, \% 80, \% 82.9, \% 88.6 olarak bulunmuş ve en az direnç ofloksasine karşı belirlenmiş̧ir (\% 8.6).

Özgümüş ve ark. ${ }^{(12)}$ tarfından 2000-2002 yılları arasında Rize'de yapılan bir çalışmada, toplam 51 adet içme suyu noktasından (36 musluk suyu ve 15 kaynak suyu) koliformların varlığını tespit etmek amacıyla 457 su örneği alınmış ve izole edilen E.coli izolatları disk difüzyon yöntemi ile antibiyotiklere direnç yönünden test edilmiştir. Tüm E.coli izolatlarının test edilen bir veya daha fazla antibiyotiğe dirençli olduğu, suşların 49'unun (\% 41.8), test edilen üç veya daha fazla antibiyotiğe dirençli olduğu ve çok dirençli fenotip olarak tanımlandığı belirtilmiştir. İzolatların yaklaşık \% 47'si ampisiline, \% 19.6'u trimetoprim-sülfametoksazole, \% 17.9'u amikasine, \% 15.3'ü netilmisine, \% 13.6'sı gentamisine, \% 12.8'si tetrasikline ve \% $2.5^{\prime} \mathrm{i}$ kloramfenikole direnç göstermiştir. Musluk ve kaynak sularından izole edilen E.coli izolatları arasında toplam antibiyotik direnç oranları arasında anlamlı bir fark olmadığı belirtilmiştir.

Patoli ve ark. ${ }^{(13)}$ Pakistan'da 2010 yılında yaptıkları bir araştırmada, 42 adet içme suyundan izole edilen 27 E.coli izolatının \% 93'ünün bir antibiyotiğe karşı dirençli olduğunu ve izolatların \% 63'ünün çoklu ilaç direncine sahip olduğunu belirtmişlerdir. En yüksek direnç nalidiksik asite (\% 92.6), ardından ampisiline (\% 88.8), seftriaksona (\% 40.7), siprofloksasine (\% 37.0), seftazidime (\% 25.2), sefotaksime (\% 18.5) ve gentamisine (\% 18.5) karşı görülmüştür. E.coli izolatların tümü amikasine karşı duyarlı bulunmuştur.

Chen ve ark. ${ }^{(3)} 2017$ yılında Çin'de yaptıkları çalışmada, içme suyu kaynaklarından izole edilen toplam 200 E.coli izolatınının antimikrobiyal ajanlara karşı direnç profilini belirlemişler ve bunlar arasında, 99 izolatın (\% 49.5) test edilen 18 antibiyotiğin en az birine karşı dirençli olduğunu ve antibiyotik direnç indeksini 0.13 olarak bildirmişlerdir. En sık antibiyotik direncinin tetrasikline (\% 42), ardından ampisiline (\% 29), piperasiline (\% 27) ve trimetoprim/sülfametoksazole (\% 25.5) karşı olduğunu bildirmişlerdir. İmipeneme ve meropeneme karşı direnç görülmemiştir. Farklı su kaynaklarından farklı mevsimlerde izole edilen E.coli izolatlarının farklı antibiyotik direnç profillerinin değişebileceğini, su kaynaklarının iyi 
korunması ve daha az yeni kirlilik sayesinde E.coli'nin antibiyotik direnç seviyelerinin azaltılabileceğini ve bazı su kalitesi parametrelerinin antibiyotik direnci seviyelerini etkileyebileceği sonucuna varmışlardır.

Hastane ortamlarında klinik örneklerden elde edilen E.coli izolatlarının antibiyotik direncini gösteren çalışmalar oldukça fazla olmasına rağmen, çevre örneklerinden izole edilen E.coli izolatlarının antimikrobiyal direncini belirleyen çalışmalar oldukça azdır ve su ortamında antibiyotik dirençli bakterilerin genotipi ve modelleri hakkında çok az veri mevcuttur.

Antibiyotiklerin yanlış ve aşırı kullanımından kaçınarak antibiyotik tüketimini azaltmak dirençli kökenlerin oluşmasını önleyen en etkili yöntemdir. Akılcı antibiyotik kullanım politikalarını belirlenmesi ve uygulanması, infeksiyonların erken tanı imkanlarının artmasıyla viral infeksiyonlar icin gereksiz antibiyotik kullanımını ve hayvan yemlerine antibiyotik katılmasını önlemek antibiyotik dirençli bakterilerin çoğalması ve çevreye yayılmasına engel olmak için alınacak önlemlerdir. Ayrıca halkın kitle iletişim araçlarıyla bilinçlendirilmesi, reçetesiz antibiyotik verilmesinin önlenmesi ve insanların antibiyotiklerin rasyonel kullanımı ve antibiyotik içeren atıkların güvenli bir şekilde bertaraf edilmesi konusunda insanlara eğitim verilmesi etkili olabilecek diğer önlemlerdir ${ }^{(11)}$.

Sonuç olarak çalışmamızdaki sınırlı sayıda suş ile saptadığımız bulgulara dayanarak, Gümüşhane ilinde içme suyundan izole edilen E.coli izolatlarının antimikrobiyal direnç paterni yönünden temel bir veri sağlanmış olup, direncin endişe verici boyutta oladığı ancak kesin bir yargıya varmak için, daha fazla izolatla yapılacak fenotipik ve genotipik çalışmalara ihtiyaç olduğu sonucuna varılmıştır.

Çıkar Çatışması: Yazarlar tarafından herhangi bir çıkar çatışması bildirilmemiş̧ir.

Conflict of Interest: No conflict of interest was declared by the authors.

\section{KAYNAKLAR}

1. Akkan T, Kaya A, Dinçer S. Hastane atık sularıyla kontamine edilen deniz suyundan izole edilen Gram negatif bakterilerin sefalosporin grubu antibiyotiklere karşı direnç düzeyleri. Türk Mikrobiyol Cem Derg. 2011;41(1):18-21.

2. Aktürk S, Matyar F, Dinçer S. Adana-Tufanbeyli yol hattındaki çeşme sularından izole edilen Gram negatif bakterilerin antibiyotik dirençlerinin incelenmesi. Türk Mikrobiyol Cem Derg. 2010;40(1):54-9.

3. Chen Z, Yu D, He S, et al. Prevalence of antibioticresistant Escherichia coli in drinking water sources in Hangzhou City. Front Microbiol. 2017;16:(8):1133. https://doi.org/10.3389/fmicb.2017.01133

4. Clinical and Laboratory Standards Institute. Performance standards for antimicrobial susceptibility testing. Twenty-first Informational Supplement. CLSI Document M100-S21, CLSI, Wayne, PA. (2014).

5. Dikbaş N, Kotan R, Dadaşoğlu F. İçme sularından izole edilen bakterilerin tanısı ve yağ asidi metil esterleri il antibiyotik duyarlılıkları arasındaki ilişkinin belirlenmesi. The Journal of Food. 2009;34(4):225-30.

6. Edberg SC, Rice EW, Karlin RJ, et al. Escherichia coli: the best biological drinking water indicator for public health protection. Symp Ser Soc Appl Microbiol. 2000;(29):106-16. https://doi.org/10.1111/j.1365-2672.2000.tb05338.x

7. Efuntoye MO, Apanpa MO. Status of contamination and antibiotic resistance of bacteria from well water in Ago- Iwoye, Nigeria. J Appl Biosci. 2010;35:2244-50.

8. Hirscha R, Ternesa T, Haberera $\mathrm{K}$, et al. Occurrence of antibiotics in the aquatic environment. Sci Total Environ. 1999;109:118. https://doi.org/10.1016/S0048-9697(98)00337-4

9. Karayakar F, Ay Ö, Cicik B. Mersin kıyı şeridinden alınan su örneklerinden izole edilen Escherichia coli suşlarının bazı antibiyotiklere karşı plasmid kökenli dirençliliğin saptanması. 
Eko Çev Kor. 2004;13(52):28-32.

10. Lyimo B, Buza J, Subbiah M, et al. Comparison of antibiotic resistant Escherichia coli obtained from drinking water sources in northern Tanzania: a cross-sectional study. BMC Microbiol. 2016;16(1):254. https://doi.org/10.1186/s12866-016-0870-9

11. Özaslan A. Adana içme suyunda fekal koliform düzeyinin belirlenmesi ve antibiyotik dirençlilik frekansı. Çukurova Üniversitesi Fen Bilimleri Enstitüsü Biyoteknoloji Anabilim Dalı, Yüksek lisans tezi, Adana (2009).

12. Özgumus OB, Celik-Sevim E, Alpay-Karaoglu S, et al. Molecular characterization of antibiotic resistant Escherichia coli strains isolated from tap and spring waters in a coastal region in Turkey. J Microb (Seoul, Korea). 2007;45(5):37987.

13. Patoli AA, Patoli BB, Mehraj V. High prevalence of multidrug resistant E.coli in drinking water sample from Hyderabad. Gomal J Med Sci. 2010;8(1):23-6.

14. Reinthaler FF, Posch J, Feierl G, et al. Antibiotic resistance of E.coli in sewage and sludge. Water
Res. 2003;37(8):1685-90.

https://doi.org/10.1016/S0043-1354(02)00569-9

15. The European Committee on Antimicrobial Susceptibility Testing. Breakpoint tables for interpretation of MICs and zone diameters. Version 1.3, January 5, (2014).

16. Türk Standardları Enstitüsü, TS EN ISO 9308-1. Su kalitesi E.coli ve koliform bakterilerin tespiti ve sayımı, Aralık (2014).

17. Vural HC, Akçin A. İzmit körfezinden izole edilen Escherichia coli'lerde R plazmidlerine bağlı "bulaşıcı tipte antibiyotik direnç özelliğinin' belirlenmesi. Kafkas Univ Vet Fak Derg. 2011;17(Suppl A):23-30.

18. Yang S, Carlson K. Evolution of antibiotic occurrence in a river through pristine, urban and agricultural landscapes. Water Res. 2003;37(19):4645-56. https://doi.org/10.1016/S0043-1354(03)00399-3

19. Wang C, Gu X, Zhang S, et al. Characterization of antibiotic-resistance Escherichia coli isolates from a lake. Arch Environ Contam Toxicol. 2013;65(4):635-41. https://doi.org/10.1007/s00244-013-9932-2 